\title{
Pharmacognostical Standardisation and HPTLC Quantification of Gallic acid in Homonoia riparia Lour
}

\author{
Seena Kanniparambil Xavier, Raviraj Anand Devkar, Shilpee Chaudhary, Chandrashekara Shastry Shreedhara and Manganahalli \\ Manjunath Setty* \\ Department of Pharmacognosy, Manipal College of Pharmaceutical Sciences, Manipal University, Manipal, Karnataka-576104, India.
}

\begin{abstract}
Background: Homonoia riparia Lour. (Family: Euphorbiaceae) is an important medicinal plant in Indian and Chinese systems of medicine used in the treatment of various medical conditions like urolithiasis, renal problems, and inflammation. This is the first report on the pharmacognostical standardisation and phytochemical evaluation of whole plant of Homonoia riparia Lour. Objective: To establish the pharmacognostical and physicochemical standardisation parameters of whole plant of Homonoia riparia Lour. Materials and Methods: The plant was studied for the morpho-anatomical characters, standardisation parameters such as ash value, extractive value, fluorescence analysis, loss on drying, swelling index, foaming index according to Indian Pharmacopoeia and WHO guidelines. Phytochemical analysis was also performed by standard methods. Quantification of gallic acid in Homonoia riparia was carried out using HPTLC technique. Results: The detailed microscopy of root revealed the presence of cork, cork cambium, pericyclic fibres, thick walled parenchyma and starch granules. The distinguishing characters of stem are presence of sclereids, xylem, phloem, fibres. Leaf microscopy showed the presence of anomocytic stomata, bicollateral vascular bundles ensheathed by fibres. Rosette crystals are present in all the parts of the plant. Starch grains are abundantly present in root and stem but absent in leaves. Various physicochemical parameters were also determined. Phytochemical screening of the extract and HPTLC quantification of gallic acid was also performed. Conclusion: The present study provides pharmacognostical, physicochemical and phytochemical details of the whole plant of Homonoia riparia which are useful in laying down standardization and pharmacopoeia parameters.
\end{abstract}

Key words: Fluorescence analysis, Gallic acid, Homonoia riparia, Microscopic evaluation, Physicochemical parameters.

\section{SUMMARY}

- Homonoia riparia is a widely used plant in Indian and Chinese system of medicine for the treatment of renal disorders, urolithiasis, malaria, and inflammation.
- An attempt has been made to establish pharmacognostical and phytochemical standardisation parameters for the plant Homonoia riparia.

- Secondary metabolite, gallic acid was detected and quantified in the methanol extract of Homonoia riparia that can be considered as a marker compound for standardisation.

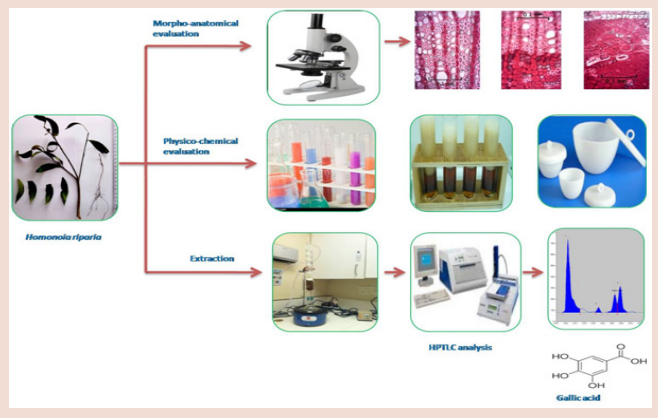

PICTORIAL ABSTRACT

Abbreviations used: HPTLC: High Performance Thin Layer Chromatography, WHO: World Health Organisation, UV: Ultraviolet, nm: Nanometer, $R_{f}$ : Retention factor.

Correspondence:

Dr. Manganahalli Manjunath Setty, Professor and Head, Department of Pharmacognosy, Manipal College of Pharmaceutical Sciences, Manipal University, Manipal, Karnataka-576104, India.

Phone no: +91-9986904482

Email: mm.setty@manipal.edu

DOI : 10.5530/pj.2015.6.12

\section{INTRODUCTION}

Homonoia riparia Lour. (Family: Euphorbiaceae) commonly known as Kshudra Pashanbhed in the Indian system of medicine grows widely across Asian countries and is planted along rivers and streams to stabilize and protect the banks. ${ }^{1}$ Historically, the plant has been used in Indian and Chinese systems of medicine for the treatment of various ailments. In Cambodia, stem and leaves are used as purgative where as wood infusion is given in malaria and scabies. Leaves are used in Malaysia and Thailand for skin infections. Traditionally, root of the plant is used in India as a laxative, emetic, diuretic, to treat urinary calculi, syphilis, gonorrhoea, malaria, antiseptic, inflammation, ulcers, urinary discharges, urinary infection, hepatitis and fungal infections. ${ }^{2-4}$ Six new cycloartane type triterepenes and quercetin glycoside have been isolated from the leaves of Homonoia riparia. $\beta$-sitosterol, stigmasterol, taraxerone, taxerol, lupenol, gallic acid, $\beta$-acetyl aleuritolic acid have been isolated from the heart wood and bark of Homonoia riparia. ${ }^{5-6}$ In addition, riparsaponine (cycloartane-type triterpenoid) was also reported from the stem of Homonoia riparia. ${ }^{7}$ Taking into consideration the medicinal potential of this plant, aim of the present study was to establish pharmacognostic standards and to identify potential marker phytoconstituents in $\mathrm{Ho}$ monoia riparia that could serve as reference standards.

\section{MATERIALS AND METHODS}

\section{Chemicals}

Analytical grade chemicals such as safranin, formalin, chloral hydrate, acetic acid, ethyl alcohol, glycerine, iodine, potassium iodide, phloroglucinol, and hydrochloric acid were used for the present study. Gallic acid was purchased from Sigma Chemicals Co, USA. HPTLC plates were obtained from E. Merck, Germany.

\section{Plant material}

Homonoia riparia was procured from the shores of Sitanadi, Karnataka in the month of February and authenticated by Dr. Gopala Krishna Bhat, Professor (Rtd.), Poorna Prajna College; Udupi and voucher specimen 
has been submitted in the herbarium of Manipal college of Pharmaceutical Sciences, Manipal. The plant material was coarsely powdered and stored in a well closed container for phytochemical analysis and determination of pharmacopoeia standards.

\section{Preparation of methanol extract}

Powdered plant material was extracted with methanol using Soxhlet extraction unit and concentrated under rotary evaporator to yield a brownish green coloured mass and was stored in refrigeration for phytochemical and High Performance Thin Layer Chromatographic analysis.

\section{Macroscopic evaluation}

The macroscopical features such as shape, texture, colour, odour and taste of the whole plant of Homonoia riparia were determined.

\section{Microscopic evaluation}

Thin transverse section of root, stem and leaf were taken using a razor blade and stained with safranin as per standard procedures and anatomical characters were distinguished under Zeiss AXIO trinocular microscope. Photographs of sections were taken using Zeiss Axio Cam attached with the microscope under bright field light. ${ }^{8}$

\section{Powder microscopy}

The whole plant material was powdered and passed through sieve number 60 and treated with phloroglucinol and concentrated hydrochloric acid and various cell characters were observed under microscope. ${ }^{9,10}$

\section{Physicochemical evaluation}

The whole plant of Homonoia riparia was subjected to various physicochemical evaluation methods such as total ash, acid insoluble ash, water soluble ash, extractive value (water and ethanol), moisture content, foaming index and swelling index as per WHO guidelines. ${ }^{11-13}$

\section{Fluorescence analysis}

Fluorescence analysis of whole plant of Homonoia riparia was carried out under visible and UV light (266 nm and $366 \mathrm{~nm}$ ) after treatment with various chemical reagents. ${ }^{14}$

\section{Phytochemical analysis}

Phytochemical analysis of methanol extract of Homonoia riparia was performed using different chemical tests in order to check the presence of secondary metabolites such as sterols, steroids, fatty acid, alkaloids, glycosides, flavonoid, and tannins in the plant by standard methods. ${ }^{15}$

\section{Quantification of gallic acid by HPTLC analysis}

CAMAG High Performance Thin Layer Chromatography (HPTLC) instrument was used for the quantification of gallic acid in the methanol extract of Homonoia riparia. ${ }^{16}$ The standard solution was prepared at a concentration of $100 \mu \mathrm{g} / \mathrm{mL}$ and test solution at $5 \mathrm{mg} / \mathrm{mL}$. Ten microlitres of the sample was applied as $8 \mathrm{~mm}$ bands on pre-coated silica gel plate using Camag Linomat 5 applicator in duplicate. The HPTLC plates were developed in solvent system, toluene: ethyl acetate: formic acid: methanol (6:6:1.8:0.25 v/v). After development, plate was dried and scanned at $280 \mathrm{~nm}$ using CAMAG TLC scanner 3 . The peak areas were recorded and percentage content of gallic acid was determined.

\section{Statistical analysis}

The experiments were carried out in triplicate and the results are reported as mean \pm standard error of mean (SEM).

\section{RESULTS}

\section{Macroscopic characteristics}

The roots arise from a common root stock and are hard, cylindrical, 5-30 $\mathrm{cm}$ long, brown in colour with attached rootlets and fibrous fracture. It has no specific odour and taste. Leaves are dorsiventral, simple, alternate and linear to lanceolate shaped, $14-22 \mathrm{~cm}$ long, and 1.6 to $2 \mathrm{~cm}$ wide. The upper surface is greenish in colour and shining whereas lower part of leaf is light green in colour and hairy. The leaves show pinnate venation, acute apex, cuneate base and entire margin. Stem is hard and nodes and internodes are present. The outer surface is brownish and inner surface light yellow in colour with no characteristic odour and taste. The fracture is fibrous (Figure 1).

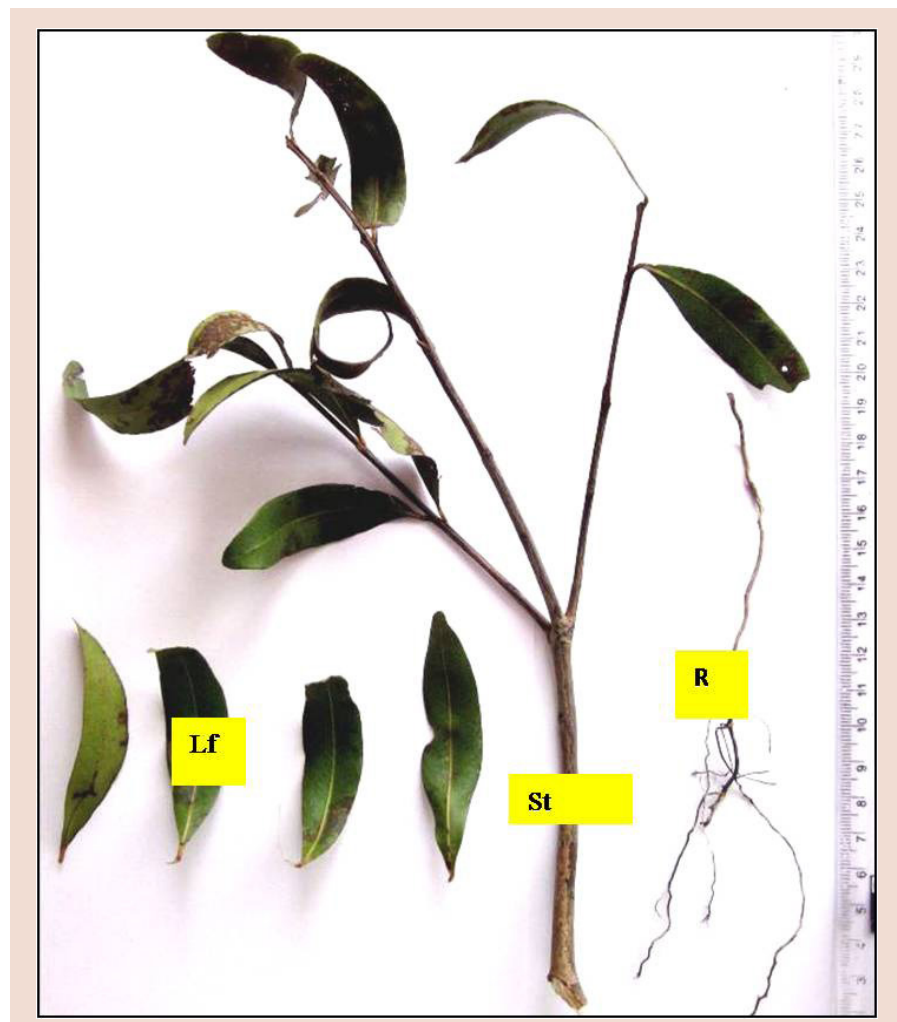

Figure 1: Whole plant of Homonoia riparia showing Lf-leaf, S-stem and R-root

\section{Microscopic characteristics}

Root

Transverse section of the root shows cork, cortex and stellar regions (Figure 2a). Cork region consist of 3-5 layers of tangentially elongated cells with deposition of brown coloured matter. Cork cambium (phellogen) is one layer thick and indistinct. Cortex consists of several layers of parenchymatous cells which are polyhedral. Group of pericyclic fibres are also present in this region (Figure $2 b$ ). Secondary xylem is chiefly made of rounded vessels, thick walled parenchyma and highly lignified fibres. Concentric starch grains are distributed in the xylem region. Radially arranged non-lignified medullary rays are visible in the phloem region and that in xylem region are lignified. Thick walled parenchymatous cells are present in the pith region with high deposition of starch grains (Figure 2c).

\section{Transverse section of leaf}

Transverse section of leaf consists of lamina and midrib regions. The lamina shows upper and lower epidermis; rectangular epidermal cells, and anomocytic stomata. Mesophyll comprises of palisade and spongy parenchyma cells filled with chloroplast. Rosette crystals are present. Palisade cells are single layered and they are cylindrical and spongy parenchyma has four layers of spherical or loosely arranged cells. Midrib exhibit crescent shaped bicollateral vascular bundle ensheathed by sclerenchymatous bundle sheath. The parenchymatous ground tissue lies 


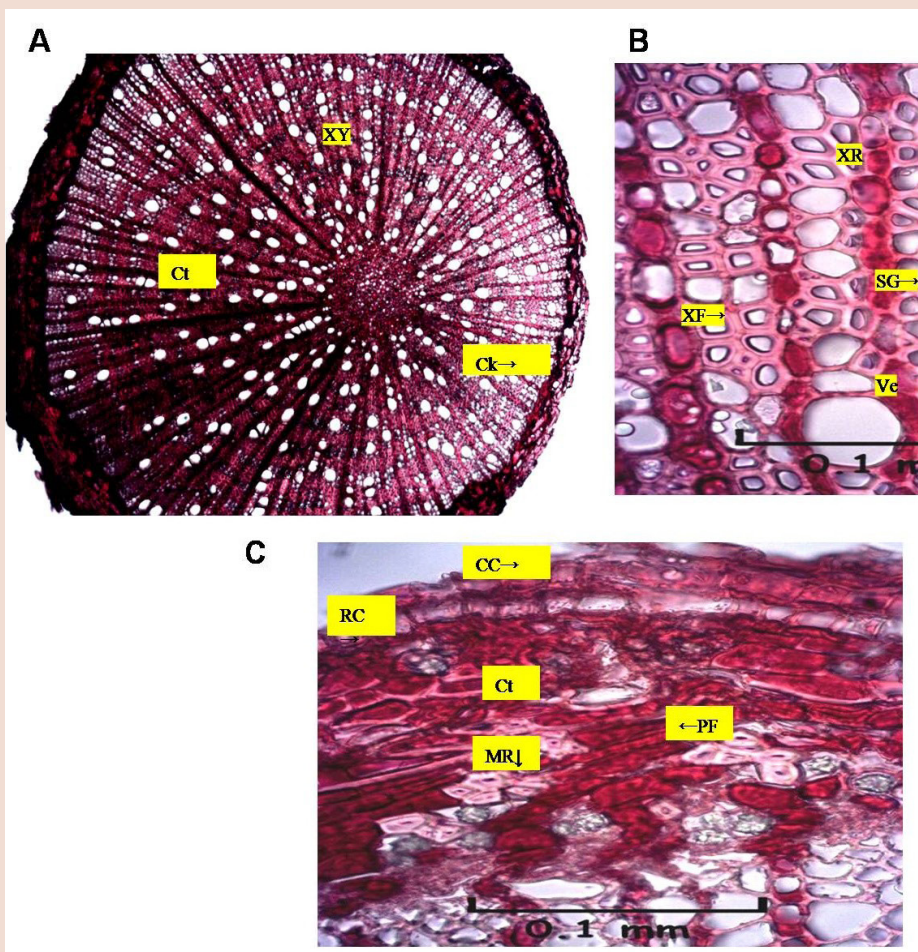

Figure 2: (A): Microscopy of root of Homonoia riparia shows Ck-cork; Ct-Cortex; XY-xylem. (B): Transverse section of the xylem region of root showing the presence of SG-Starch grains, Ve-Xylem vessels; XR-xylem rays; XF-Xylem fibres. (C): Enlarged portion of cork and cortex region of root showing CC-Cork cambium; MR-Medullary rays; PF-Phloem fibres; Ct-Cortex; RC-Rosette crystal

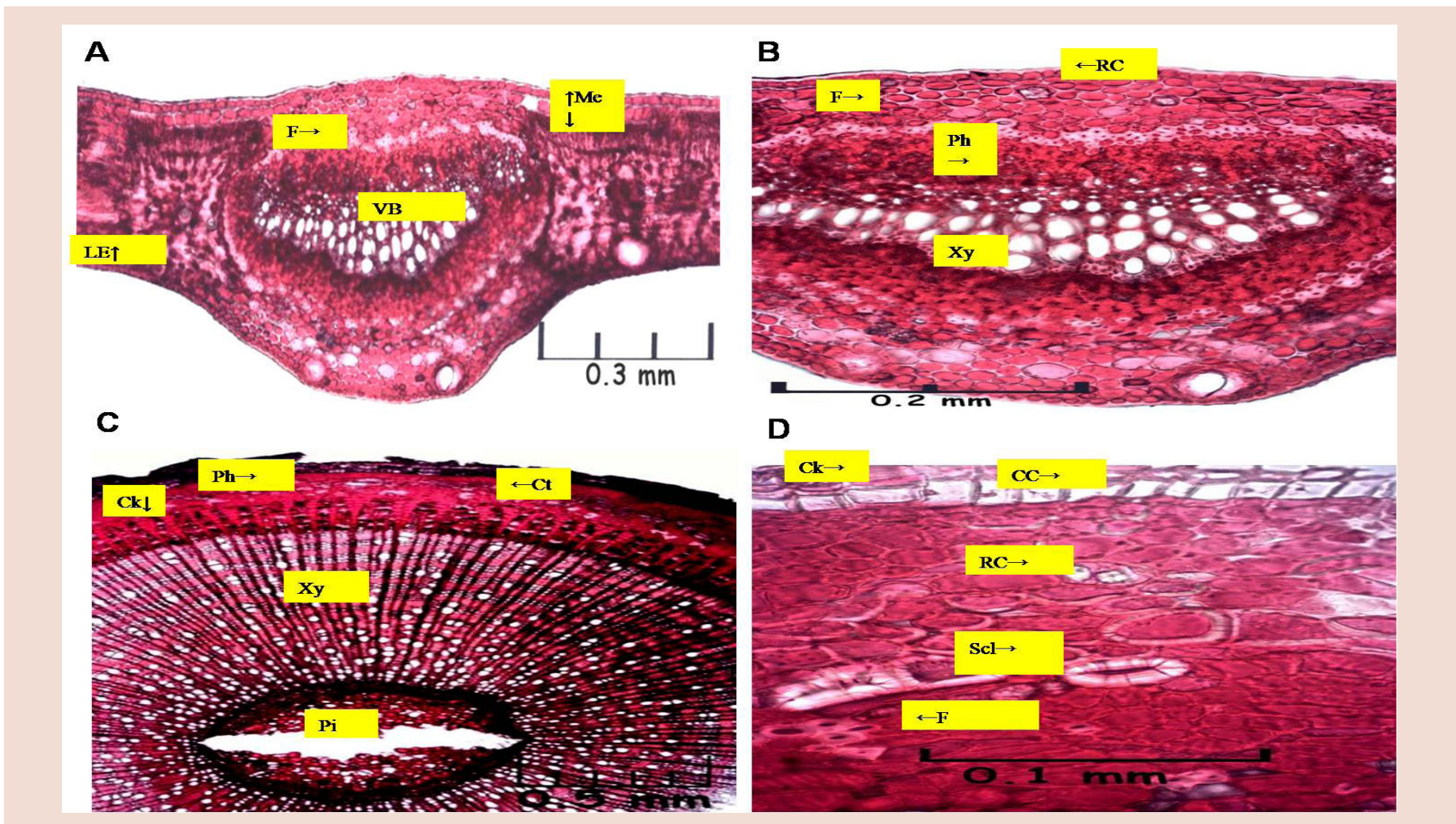

Figure 3: (A) Microscopy of leaf of Homonoia riparia showing. F-fibre; LE-lower epidermis; Me-mesophyll; Pal-palisade; Ph-phloem; RC-rosette crystal; SPspongy parenchyma; UE-upper epidermis; Xy-xylem. (B) T. S of midrib showing. F-fibre; LE-Lower epidermis; Ph-Phloem; RC-Rosette crystal; VB-Vascular bundles; Xy-Xylem. (C) Transverse section of stem showing. Ck-cork; Ct-cortex; F-fibres; Ph-phloem; Xy-xylem fibres; Pi-pith. (D) Microscopy of cork and cortex region of stem showing Ck-Cork; CC-Cork cambium; Scl-Sclereids; RC-Rosette crystal; F-fibre 
next to bundle sheath. Xylem and phloem are the components of the vascular bundle. Starch grains are absent. (Figures $3 \mathrm{a}$ and $3 \mathrm{~b}$ ).

\section{Stem}

Transverse section of mature stem shows phellem consisting of 3-5 layers of tangentially elongated cork cells with highly suberised walls. The phellogen (cork cambium) is single layered consisting of radially elongated thin walled cells. Phellogen is followed by phelloderm and cortex, indistinghuisble from each other; consisting of 10-12 layered loosed thin walled parenchymatous cell. Stone cells, a reduced form of sclerenchyma cells appears either solitary or in groups of two to three cells, pitted and highly thickened. Cortex is followed by secondary phloem consisting of phloem parenchyma, phloem fibres with narrow lumen, and uniseriate medullary rays. Secondary cortex also contains rosette calcium oxalate crystals. Pith region consists of parenchymatous cells and group of pericyclic fibres. Simple, granular starch grains are present in the phloem, xylem, ray and pith region (Figures $3 \mathrm{c}$ and $3 \mathrm{~d}$ ).

\section{Powder microscopy}

Powdered drug of Homonoia riparia was yellowish brown, odourless and coarse in texture. Microscopically, the powder showed lignified fibres, cork cells, spirally annulated xylem vessels and anomocytic stomata (Figure 4).

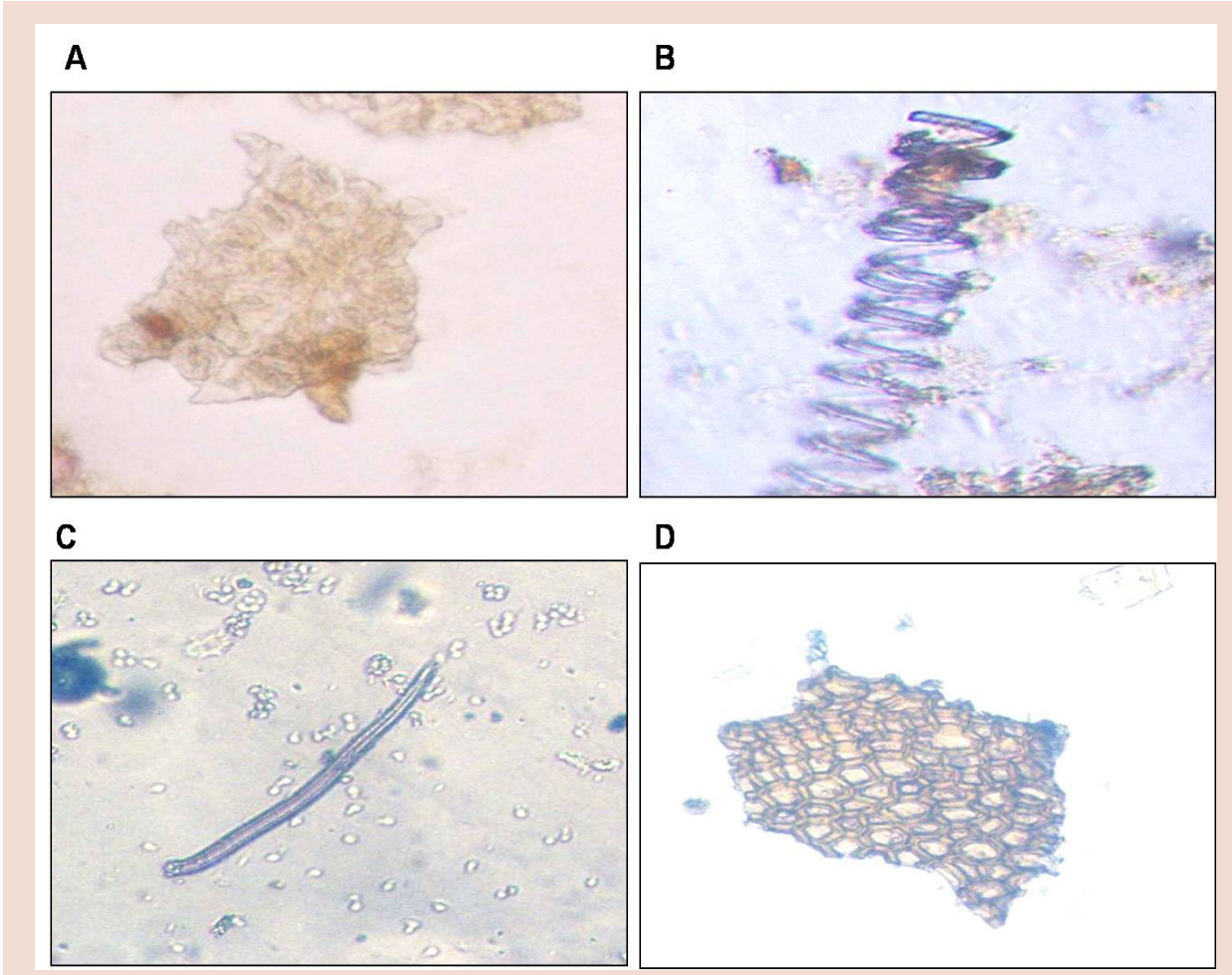

Figure 4: Powdered characteristics of the whole plant of Homonoia riparia showing A) St-Anomocytic stomata; B) XV-Spiral xylem vessels; C) Lignified fibres D) Ck- Cork cells.

Table 1: Ash values of Homonoia riparia

\begin{tabular}{cc}
\hline Parameters & Value $\%$ w/w \\
\hline Total ash & $5.02 \pm 0.59$ \\
Water soluble ash & $3.38 \pm 0.05$ \\
Alcohol insoluble ash & $1.175 \pm 0.74$ \\
\hline
\end{tabular}

Table 2: Extractive values of Homonoia riparia

\begin{tabular}{cc}
\hline Parameters & Value $\% \mathrm{w} / \mathrm{w}$ \\
\hline Alcohol soluble extractive value & $6.93 \pm 0.01$ \\
Water soluble extractive value & $11.4 \pm 0.02$ \\
\hline
\end{tabular}

Table 3: Moisture content, foaming index and swelling index of Homonoia riparia

\begin{tabular}{cc}
\hline Parameters & Values \\
\hline Moisture Content & $6 \pm 0.61(\% \mathrm{w} / \mathrm{w})$ \\
Foaming Index & $111.11 \pm 0.3$ \\
Swelling Index & $4 \pm 0.1$ \\
\hline
\end{tabular}

\section{Physicochemical evaluation}

Ash value determination is useful for identifying low quality product, earthy matter or excess of sandy matter or impurities present with drug. The percentage of total ash, acid insoluble ash and water soluble ash were calculated. The results are shown in Table 1. Extractive values are use- ful to indicate the nature of chemical constituents and also for the identification of adulteration. The extractive values (ethanol and water) are presented in Table 2. The moisture content, swelling index and foaming index were calculated and shown in Table 3 . The fluorescence analysis of sample drug is tabulated in Table 4 . 
Table 4: Fluorescence analysis of Homonoia riparia

\begin{tabular}{|c|c|c|c|}
\hline \multirow{2}{*}{ Treatments } & \multirow{2}{*}{ Visible light } & \multicolumn{2}{|c|}{ UV light } \\
\hline & & Short wave $(264 \mathrm{~nm})$ & Long wave (366 nm) \\
\hline Powder as such & Light brown & Blackish brown & Black \\
\hline $\begin{array}{l}\text { Powdered drug }+ \text { concentrated } \\
\text { hydrochloric acid }\end{array}$ & Brown & Brown & Black \\
\hline $\begin{array}{l}\text { Powdered drug + concentrated } \\
\text { hydrochloric acid }\end{array}$ & Reddish Brown & Yellowish brown & Black \\
\hline Powder + glacial acetic acid & Black & Black & Black \\
\hline Powder $+5 \mathrm{~N}$ sodium hydroxide & Brown & Yellowish Brown & Black \\
\hline $\begin{array}{l}\text { Powder + aqueous iodine } \\
\text { solution }\end{array}$ & Brown & Brown & Black \\
\hline
\end{tabular}

\section{Phytochemical analysis}

Methanol extract of Homonoia ripria indicated the presence of primary and secondary metabolites such as carbohydrates, sterols, flavonoids, phenolic compounds, tannins, saponins etc (Table 5).

Table 5: Preliminary phytochemical screening of Homonoia riparia

\begin{tabular}{cc}
\hline Phytoconstituents & Methanol extract \\
\hline Alkaloids & - \\
Carbohydrates & + \\
Sterols and triterepenoids & + \\
Saponins & + \\
Fixed oils and fats & - \\
Phenolic compounds and tannins & + \\
Proteins and amino acids & - \\
Flavonoids & + \\
\hline
\end{tabular}

\section{Quantification of gallic acid by HPTLC}

Presence of gallic acid in the methanol extract of Homonoia riparia was confirmed by HPTLC analysis and the percentage of gallic acid $\left(\mathrm{R}_{\mathrm{f}} 0.56\right)$ was found to be $0.76 \% \mathrm{w} / \mathrm{w}$ (Figure 5 ).

\section{DISCUSSION}

Quality control standards of herbal medicine used in indigenous systems of medicine have become highly applicable due to the reawakening of interest in these drugs all over the world. In the present study, the morphological, microscopical, physicochemical and phytochemical characteristics of the whole plant of Homonoia riparia have been reported. Morphological and microscopical parameters were established to authenticate the genuine drug. These features will be useful for easy and quick identification of the right variety and adulterants. The physical evaluation of the crude drugs plays an important criterion in detecting adulteration or improper handling of drugs. ${ }^{17}$ Physicochemical reports showed that total ash value was $5.02 \% \mathrm{w} / \mathrm{w}$, acid insoluble ash was $1.18 \%$ $\mathrm{w} / \mathrm{w}$, water insoluble ash was $3.38 \% \mathrm{w} / \mathrm{w}$, foreign organic matter $0.7 \%$ $\mathrm{w} / \mathrm{w}$, and alcohol soluble extractive value was $6.93 \% \mathrm{w} / \mathrm{w}$ and water soluble extractive value was $11.4 \% \mathrm{w} / \mathrm{w}$. The moisture content of drug was found to be considerably high (Table 3 ). Lower moisture content indicates better stability against decomposition of the drug and it should be reduced to avoid decaying of the crud drug by chemical change or microbial attacks. The results of the phytochemical screening of whole plant of Homonoia riparia indicated the presence of terepenoids, flavonoids, phytosterols, phenolic compounds, tannins, saponins which might show therapeutic potential in further biological investigations. Gallic acid and its structurally related compounds are biologically active phytoconstitu-
A

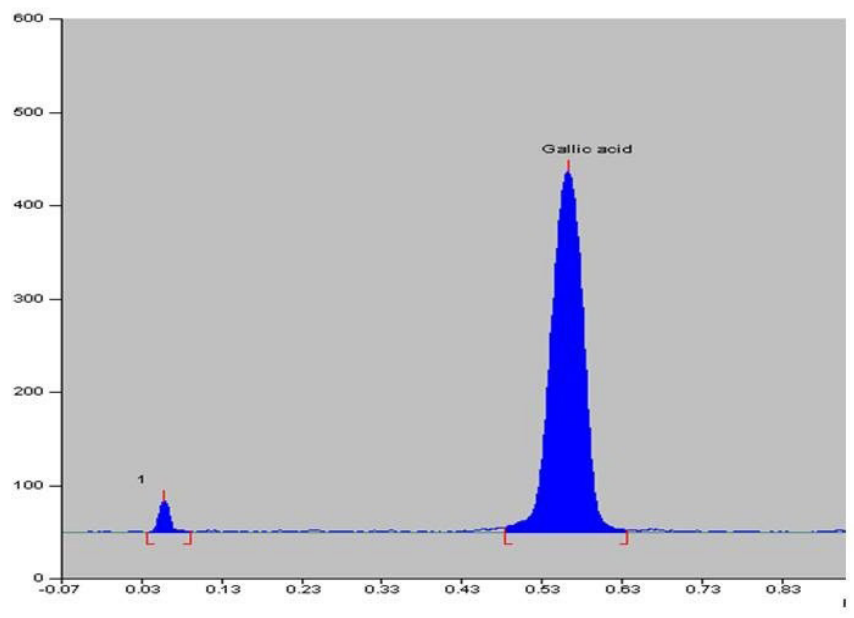

B

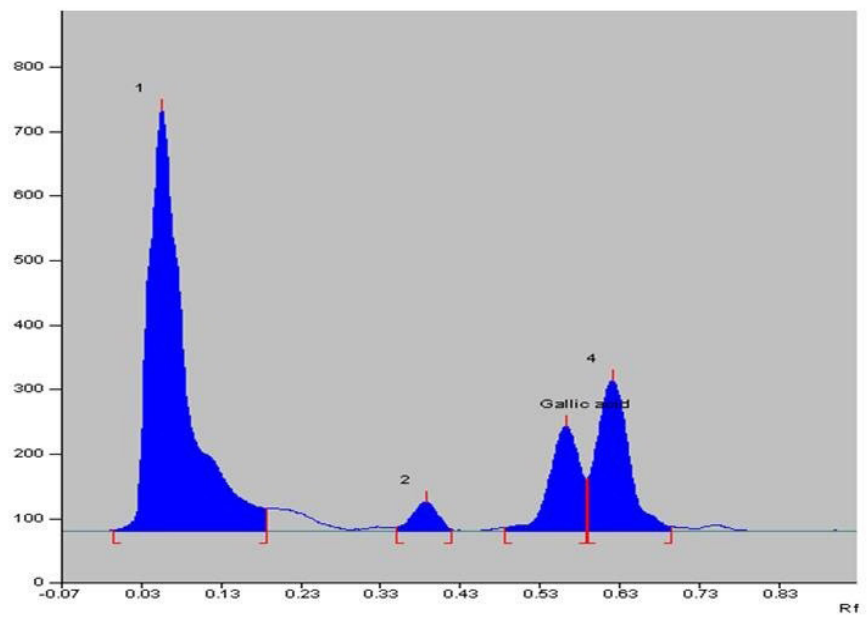

Figure 5: HPTLC analysis of methanol extract of Homonoia riparia with phytomarker gallic acid. HPTLC chromatographic profile of (A) Standard gallic acid ( $R_{f}$ value 0.56$)$; (B) $H R M$; $\left(R_{f}\right.$ value 0.56 indicate the presence of gallic acid) 
ents widely seen in fruits and plants ${ }^{18}$ and are found to possess number of pharmacological activities such as anticancer, ${ }^{19}$ anti-inflammatory, ${ }^{20}$ cardioprotective, ${ }^{21}$ hepatotprotective, ${ }^{22}$ and renoprotective activities. ${ }^{23}$ Marker compound based standardization has been demonstrated to be a valid method for the identification of botanical medicine and formulations. The percentage of marker compounds serve as an indicator of the quality of plant materials. ${ }^{24}$ In the present study, significant quantity of gallic acid was detected and quantified in the methanol extract of Homonoia riparia that could act as a marker for standardization.Till date, there are no reports of the pharmacognostical standardization of Homonoia riparia, therefore, our study will provide significant information for identification and authentication of plant material and serve as a quality control for future reference.

\section{CONCLUSION}

The present study was carried out to establish the detailed pharmacognostical and physico phytochemical parameters of the plant Homonoia riparia that will aid in the correct authentication and identification of the plant material.

\section{ACKNOWLEDGEMENT}

We are thankful to Manipal College of Pharmaceutical Sciences, Manipal University, Manipal for providing the facilities to conduct the research work and express sincere thanks to All India Council of Technical Education (AICTE), New Delhi for the financial support under Quality Improvement Programme (QIP) scheme.

\section{CONFLICTS OF INTEREST}

The authors declare no conflicts of interest.

\section{REFERENCES}

1. Hanum F, Vander Maesen LJG. Prosea: Plant Resources of South-East Asia 11 Auxiliary Plants. $2^{\text {nd }}$ ed. Indonesia: Prosea Foundation; 2007. p. 155.

2. Khare CP. Indian medicinal plants-An illustrated dictionary. Newyork: Springer Science Business media; 2007. p. 314.

3. Quaattrocchi U. CRC World dictionary of medicinal plants and poisonous plants. Boca Raton: Taylor and Francis group; 2012. p. 2002.

4. Prasad KVSRG, Abraham R, Bharathi K, Srinivasan. Evaluation of Homonoia riparia
Lour forantiurolithiatic activity in albino rats. Int. J.Pharamacogn. 1997; 35(4): 278.

5. Viswanad GS, Atchutha R, Laatsch $H$, Rajendar M. Chemical constituents of heartwood and bark of Homonoia riparia. J. Trop. Med. Plants 2006; 7(2): 267-73.

6. Yang SM, Liu XK, Qing C, Wu DG, Zhu DY. Chemical constituents from root of Homonoia riparia. Acta Pharm Sin B. 2007; 42(3): 292-6.

7. Fan X, Xuegian Z, Lingli Y, Xiuhua W, Jing Z. A New Cycloartane-Type Triterpenoid Saponin Xanthine Oxidase Inhibitor from Homonoiar iparia Lour. Molecules 2014; 19(9): 13422-31.

8. Wallis TE. Text book of Pharmacognosy. $5^{\text {th }}$ ed. London: TA Churchill; 1985. p. 575-82.

9. Evans WC. Trease and Evans Pharmacognosy. $12^{\text {th }}$ ed. London: BaillereTindall; 1983. p. 538-47.

10. Dinesh K, Ajay K, Om P. Pharmacognostic evaluation of stem bark of Pongamia pinnata (L.) Pierre. Asian Pac J Trop Med. 2012; 2(2): 543-7.

11. Government of India. Indian Pharmacopoeia. $4^{\text {th }}$ Ed. New Delhi: Ministry of health and family welfare, Controller of publication; 1996. p. A53-4

12. WHO. Quality control methods for medicinal plant materials. Geneva: World Health Organisation; 1998. p. 13-51.

13. Khandelwal KR. Practical Pharmacognosy. $13^{\text {th }}$ ed. Pune: Nirali Prakashan; 2005. p. 149-60.

14. Kokoski J, Kokoski R, Slama FJ. Fluorescence of powdered vegetable drugs under ultraviolet radiation. J. Am. Pharmacol Assoc. 1958; 47(10): 715-7.

15. Harbone JB. Methods of extraction and isolation, In: Phytochemical Methods. London: Chapman and Hall; 1998. p. 60-6.

16. Tandon N, Sharma M. Quality standards of Indian medicinal plants. Volume 1 , New Delhi: Indian Council of Medical Research (ICMR); 2003. p. 203.

17. Kunle Oluyemisi F, Egharevba, Henry O, Ahmadu Peter O. Standardization of herbal medicines-A review. Int. J. Biodivers. Conserv. 2012; 4(3): 101-12.

18. OW YY. Stupans I. Gallic acid and gallic acid derivatives: effects on drug metabolizing enzymes. Curr Drug Metab. 2003; 4(3): 241-8.

19. Samuel K, Naresh K, Padmaja G. Isolation and characterization of gallic acid and methylgallate from the seed coats of Givotia rottleriformis Griff. and their anti-proliferative effect on human epidermoid carcinoma A431 cell. Toxicology 2015; 2: 520-9.

20. Kroes BH, Van Den Berg JJ, Quarles Van Ufford HC, Van Dijk H, Labadie RP. Ant-inflammatory activity of gallic acid. Planta Med. 1992; 58(6): 499-504.

21. Snehal SP, Ramesh KG. Cardioprotective effects of gallic acid in diabetes-induced myocardial dysfunction in rats. Pharmacognosy Res. 2011; 3(4): 239-45.

22. Vijaya PV, Sowmya P, Arun FT, Baskaran R, Poornima P. Protective effect of gallic acid against lindane induced toxicity in experimental rats. Food Chem Toxicol. 2011; 49(4): 991-8.

23. Rasool MK, Sabina EP, Ramya SR, Preety P, Patel S, Mandal N, et al. Hepatoprotective and antioxidant effects of gallic acid in paracetamol-induced liver damage in mice. J. Pharm Pharmacol. 2010; 62(5): 638-43.

24. Songlin L, Quanbin H, Chunfeng Q, Jingzheng S, Chuen LC, Hongxi X. Chemical markers for the quality control of herbal medicines: an overview. Chin Med. 2008; 3(1): 7-10.

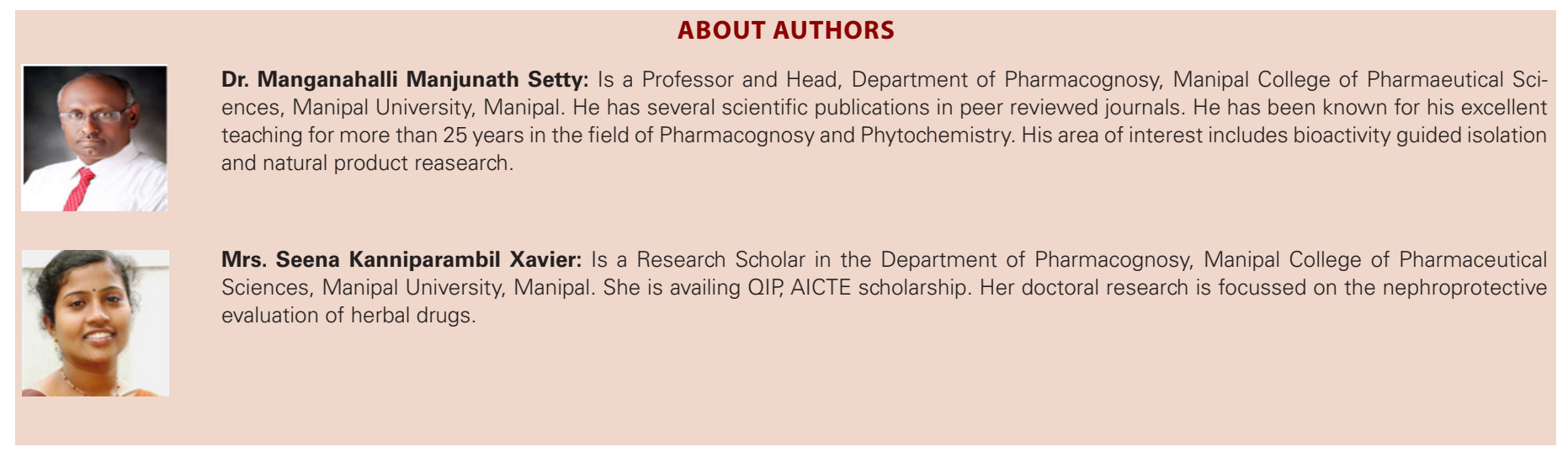

